\title{
ARCHAEOLOGICAL SITES FROM ANTIQUITY REGISTERED IN THE SURROUNDINGS OF HOT SPRINGS ALONG THE DANUBIAN LIMES IN SERBIA
}

\begin{abstract}
Along the Roman limes (the part located in today's Serbia) there were several hot springs. Alongside some of them, archaeological sites were registered, which would suggest the possibility that those hot springs were exploited in Antiquity. This paper gives an overview of the sites and findings discovered in the vicinity of the hot springs at Milutinovac, Boljetin, Višnjička Banja, Leštane, Vrdnik, Slankamen and Erdevik.
\end{abstract}

KEYWORDS: LIMES, DANUBE, ARCHAEOLOGICAL SITES, HOT SPRINGS, SERBIA, MILUTINOVAC, BOLJETIN, VIŠNJIČKA BANJA, LEŠTANE, VRDNIK, SLANKAMEN AND ERDEVIK.

Bearing in mind some basic theoretical demands, on one hand, as well as, on the other hand, the complexity and diversity of the geological structure of the territory of Serbia, and the existing structure -geological, geomorphological, hydrogeological, physical-geographical and other circumstances, B. Filipovic divided the territory of Serbia into the following six hydrogeological regions:

1. Dacian Basin region

2. Carpatho-Balkan region

3. Serbian crystalline core region

4. Šumadija-Kopaonik-Kosovo region

5. Dinaric region in Western Serbia

6. Pannonian basin region (Филиповић 2003: 15).

The subject of this paper is the archaeological findings (mobile or otherwise) from Antiqui- ty discovered in the vicinity of hot springs in the area of the part of the Danubian limes which is located in the territory of today's Serbia. The goal of this paper is to establish whether those healing water springs alongside the Danubian limes were known and exploited during Antiquity. In order to determine a possible continuity of exploitation of those springs, prehistoric and medieval layers will also be mentioned, registered on sites for which we have confirmed that they existed in Antiquity.

Sites registered at Milutinovac (Dacian Basin region), Boljetin (Carpatho-Balkan region), Višnjica and Višnjička Banja, Leštane (Šumadija-Kopaonik-Kosovo region), Vrdnik, Slankamen and Erdevik (Dinaric region in Western Serbia) will be presented in the paper.

\section{MILUTINOVAC}

\begin{tabular}{|c|c|c|c|}
\hline Early Byzantine period & & Fortification & $6^{\text {th }}$ century \\
\hline
\end{tabular}

Milutinovac is a settlement in the municipality of Kladovo, in the Bor District.

The existence of hot springs at Milutinovac was not noted in B. Filipović's overview. Howev- er, traces of the existence of a former water source were noted by F. Kanitz. The traveller noted that it ran beneath the hill of Čuka Mare (altitude above sea level, 366 metres), to the northeast from Mi- 
lutinovac, where there were, incidentally, the remains of an earth fort from the First Serbian Uprising, according to Kanitz, built on foundations from Antiquity: "At the bottom of this sharply profiled hill there is a source of rather tasty warm salty water; because of that, not far from the village which was inhabited three decades ago by people from Montenegro, test drills were made eighteen years ago in hope of finding salt, but to no avail" (Каниц 1989: 481-482).

Kanitz noted that there was a rectangular fort in the village of Milutinovac, approximately $50 \mathrm{x}$ 60 metres in dimensions, certain parts of which were preserved up to the height of two metres. The traveller thought that the remains of the fort would disappear in a very short span of time (Каниц 1989: 481-482).

The fort, whose local name remains unknown, was provisionally identified by P. Milošević and M. Jeremić as Timena, a fort registered by Procopius. It was erected on the spot where the Danube is at its' narrowest, so as to enable the control of a large, nearby sandbank, whose existence additionally facilitated the crossing of the Danube. Since the site was put in danger by the building of the hydro-power plant Đerdap II, archaeological excavations were conducted (Milošević i Jeremić 1986: 245).

Research has shown that it was an early Byz- antine fortification from the $6^{\text {th }}$ century, of approximate dimensions $48-49.90 \times 54 \mathrm{~m}$ on the inside, and $51.80-53.30 \times 57.80 \mathrm{~m}$ on the outside. The corners of the fortification where strengthened with one circular (southern tower) and three ellipsoid towers. The existence of a quadrangular tower was registered in the middle of the oval rampart, and the entrance into the fort was probably there as well. On the inner side of the rampart, parts of stair constructions were discovered, and also the exit to the footpath. The width of the rampart is $1.90-1.95 \mathrm{~m}$. When it comes to mobile findings, fragments of early Byzantine amphorae and half folles of Justin II were found, dated into the seventh decade of the $6^{\text {th }}$ century (Milošević $i$ Jeremić 1986: 246-249).

The location of the fort at Milutinovac was certainly chosen because of strategic reasons, most prominently the fact that it was built at the point where the Danubian Ključ is the narrowest. However, we do believe that the existence of a nearby hot spring significantly influenced the everyday life of the people manning the fort, hence, this site can be put on the list of those connected to healing springs. The noted existence of a former hot spring at Milutinovac influences the opinion that similar springs, which no longer exist, could have been present alongside other sites in the region as well.

\section{BOLJETIN}

\begin{tabular}{|c|c|c|c|}
\hline Antiquity & fort & $\begin{array}{c}1^{\text {st }}-\text { beginning } \\
\text { of the } 5^{\text {th }} \text { century }\end{array}$ \\
\hline Early Byzantine period & & fort & $6^{\text {th }}$ century \\
\hline Middle Ages & & necropolis & $10^{\text {th }}-11^{\text {th }}$ century \\
\hline
\end{tabular}

Boljetin is a village in Serbia in the Municipality of Majdanpek, in the Bor District.

The existence of a hot spring at Boljetin was noted by Felix Kanitz. There are no mentions of the existence of that spring in modern literature. The traveller wrote that the Antique fort, not far from the confluence of the Boljetin river with the
Danube, is located "on the opposite side of the hot spring which originates from the very river, not far from the bank" (Каниц 1985: 214).

The existence of a military encampment was registered in the area of Boljetin, used from the $1^{\text {st }}$ until the $6^{\text {th }}$ century. It was built in the first half of the $1^{\text {st }}$ century, as an earth fort with palisades. 


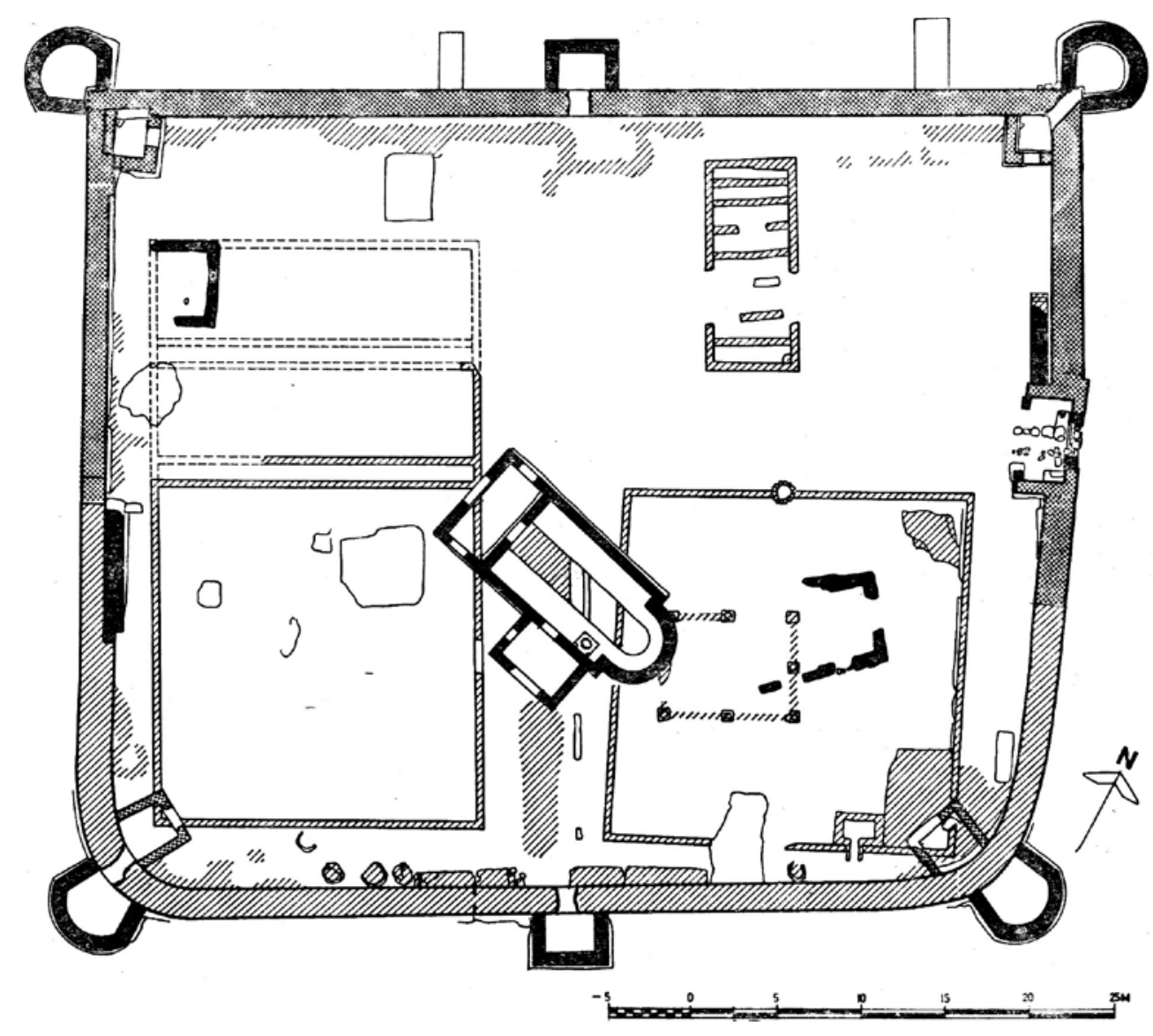

Fig. 1. The ground plan of the fortification at Boljetin, according to: Зотовић 1982/1983: 213, сл. 2.

During the second half of the $1^{\text {st }}$ century, ramparts were built. The fortification was abandoned in the $2^{\text {nd }}$ century, maybe during the reign of Hadrian. It was rebuilt for the first time just before Aurelian left Dacia. It was destroyed in a great fire in the first decades of the $5^{\text {th }}$ century and was rebuilt for the second time during Justinian's great restoration in the $6^{\text {th }}$ century (Зотовић $1982 / 1983: 211$ ).

The dimensions and internal organisation of the earth fort remain unknown. Conclusions about it can be drawn from its stratigraphy and analysis of architectural remains from the $1^{\text {st }}$ century. Remains of the fortification from the second half of the $1^{\text {st }}$ century were noted only in the south-eastern half of the encampment. The dimensions of the oldest fortification have not been precisely established. We do know that the north-eastern to south-western axis corresponded to the length of the axis of the restored fortification, while the north-west- ern to south-eastern axis was somewhat longer than the axis of the fortification in the following building phase. In this phase, the fortification was manned by soldiers from the IV Flavia Legion. The destruction of the fortification occurred on the north-western side, from the direction of the Boljetin river, in the area of its confluence with the Danube ((Зотовић 1982/1983: 214-215).

There are several objects from this period preserved in the inner part of the fortification. Object 1 is especially interesting to us, built from polygonally cut mortared stone blocks. The entrance into the object was located in the south-western wall, directly beneath the apse of the later church, and it connected the object and the porch that ran along the street. In the middle section of the south-western half of the object, some 2.50 meters from the south-western wall, there was a porch with a rectangular base. On the corners of the porch, there 
are four plinths from well-shaped tufa for columns or pillars. Since no parts of columns were found, it is possible that it was a wooden construction. Remains of a mortar floor were discovered in the inner part of this area. Alongside the southern wall, in the eastern part of the object, a small chamber was added, with a hypocaust, with dimensions of $7.20 \times 1.10 \mathrm{~m}$. The walls of the room, $40 \mathrm{~cm}$ thick, were made of brick and crushed stone. The mortar on the walls and the floor had admixtures of crushed bricks. Three hypocaust pillars were registered. The prefurnium was located on the outer side of the south-eastern wall of the building. Since the possibility of the existence of a pool was eliminated, it is probable that the hypocaust room had the function of a sudatorium. The object was seriously damaged when a church and another object were built in a later period (Зотовић 1982/1983: 215-216).

These items were certainly the remains of a Roman bath, above which a Christian religious object was raised, because of its shape, but maybe also because of the importance linked to the use of hot water from the nearby hot spring.

The other object discovered from the same building phase represents the remains of a horre$u m$, and traces of three furnaces were registered as well. There were paved streets in the encampment, oriented towards the entrances on the ramparts (Зотовић 1982/1983: 217-218).

During the first restoration of the fort, just before Aurelian left Dacia, the three preserved ramparts were rebuilt, while the north-western rampart and the northern half of the north-eastern rampart were built from the foundations. On this occasion, the inner towers of the fortification were built. The inside of the fortification, in this phase, was filled with tents, organised in almost regular lines along the north-eastern to south-western axis. It is assumed that the encampment was manned by a part of the VII Claudia Legion in this period. The encampment is believed to have been abandoned in the first decades of the $5^{\text {th }}$ century. The time when the encampment was abandoned was marked by a layer of debris, while traces of fire can be noted in the eastern part only (Зотовић 1982/1983: 220-222).

In the time of the Early Byzantine restoration of the limes, the fortification at Boljetin was restored as well. It is believed that on that particular occasion only the relatively well preserved ramparts from earlier stages were rebuilt or partially restored and adaptations at the gates made, while the outer towers were built from the foundations. As we have already mentioned, in the central part of the fort, above the Roman bath, a church was built, with the inner dimensions of $15 \times 5.50 \mathrm{~m}$, oriented along the axis east-west. The base of the church is a rectangular naos with a semi-circular apse and a rectangular narthex. Along the southern wall of the naos, in its eastern half, following its contour, a rectangular paraclis was added. On the inner side of the wall of the apse, following its contour, a stair-shaped part was added, probably a base for seats. On the inner side of the southern wall of the naos, a baptistery was added, with dimensions of $1.20 \times 1 \mathrm{~m}$. All parts of the church were built by alternating well-shaped and crushed stone and brick. The church represented, in its restored or even levelled, demolished state, a cult place linked to the medieval necropolis. It is possible that the remains of the church were not visible in this period, but rather that it remained embedded in the conscience of the population as a cult place were burials were performed (Зотовић 198/1983: 223-224).

When it comes to buildings from the final phase of the fortification, the existence of two workshops was registered. The military was, again, living in tents, whose layout was significantly sparser than the one noted in the previous phase, which indicates that the number of soldiers in the fortification was significantly diminished. On the basis of numismatic findings, it was concluded that this temporary period in the fortification came to an end in the last years of the $6^{\text {th }}$ century, when the encampment was destroyed in a big fire (Зотовић 1982/1983: 225). V. Kondić identified the fortifi- 
cation at Boljetin as Smorna, which was registered by Procopius (Кондић 1971: 54-58).

During research at the medieval necropolis, established within the ramparts of the fortification from the Antiquity period, the presence of 97 skeletal graves was recorded. It was established that one grave, marked with number 72 , belongs to the Roman period. It was a child's grave, oriented along the south-eastern to north-western axis, facing northwest. It was discovered under an intact construction made of daub. There were no grave offerings. Other graves belong to the medieval necropolis, dated into the period of the $12^{\text {th }}-14^{\text {th }}$ century (Ерцеговић-Павловић 1982/1983: 227-230).

During the research of the necropolis, in the Early Byzantine layer, a hoard was discovered consisting of eleven lunular earrings made of copper and bronze, decorated using the filigree technique, which S. Ercegović-Pavlović attributed to the Slav population and dated into the $10^{\text {th }}-11^{\text {th }}$ century (Ерцеговић-Павловић 1969: 83-95).

In our previous papers, we gave evidence of the long lasting and continuous life at Boljetin, i.e. Antique and Early Byzantine Smorna. We didn't obtain an answer to the question regarding the importance that the hot spring, registered by Kanitz, had on the functioning of the fortification. It is probable that the strategic position of this location was of primary importance for choosing the place for the castrum. However, we believe that the easily available hot spring was very important for the everyday lives of the soldiers and all others who sojourned at the castrum or its immediate surroundings. The presence of a Roman bath in what was practically the centre of the fortification, with a relatively small surface area and with hypocaust heating, suggests the possibility that water from the hot spring was used in the bath. It is easy to assume that, if that was the case, a certain cult worshiping developed for the hot springs, inspiring such a feeling towards the place where that water was used as well - i.e. the balneum. The importance of the cult place continued through the Early Byzantine basilica and the medieval necropolis.

Višnjička Banja is a settlement within the area of Višnjica. It was named after a hot spring, originating from the bank of the Dunavac. The temperature of the water is $14.4^{\circ} \mathrm{C}$, and its $\mathrm{pH}$ level is 7.5. The water is characterised by the presence of hydrogen sulphide (Филиповић 2003: 76).

The first mentions of archaeological sites at Višnjica, at the beginning of the $20^{\text {th }}$ century, were provided by M. M. Vasić, who mentions the findings from the Žuto Brdo culture. Data can be

VIŠNJICA AND VIŠNJIČKA BANJA

\begin{tabular}{|c|c|c|c|}
\hline Bronze Age & $\begin{array}{c}\text { The culture of Žuto } \\
\text { Brdo }\end{array}$ & SETTLEMENT & \\
\hline La Tène period & & Pottery & \\
\hline & & $\begin{array}{c}\text { - Buildings } \\
\text { - Votive inscription (?) } \\
\text { - Ring with a carnelian gem } \\
\text { - Coins } \\
\text { Antiquity }\end{array}$ & $\begin{array}{c}\text { - The site of Bela Stena }- \\
\text { four tombs made of bricks }\end{array}$ \\
\hline Early Middle Ages & & $\begin{array}{c}\text { The site of Bela Stena } \\
\text { Byzantine, Sarmatian-Iazy- } \\
\text { gian and Slav pottery }\end{array}$ & \\
\hline Middle Ages & & $\begin{array}{c}\text { There were remains of a } \\
\text { round tower on the bank of } \\
\text { the Danube and a medieval } \\
\text { monastery }\end{array}$ & \\
\hline
\end{tabular}


found related to a broken urn, found somewhere between Višnjica and Veliko Selo, which contained a bronze bracelet, a bronze plummet and two bronze nails. That data was insufficient for dating the urn more precisely. In the Belgrade City Museum, several fragments of La Tène pottery are kept, found in the western part of the settlement (Гарашанин, Д. 1954: 58).

In the area of Višnjica, several objects were found, dated into the Roman period. Thus, Kanitz noted that, in the place where "the monastery of Dušice, in which, it is said, Kraljević Marko was buried" was (as Milićević wrote), he had found "undoubtedly intact walls of a Roman fortification” (Каниц 1985: 152).

The finding of a votive inscription is also interesting, though Vulić believed that there was a possibility that it was, in fact, a forgery (Вулић 1909: 143). Antefixes were also discovered at Višnjica masks placed on a building (Гарашанин, Д. 1954: 94).

Also originating from this area are the accidental findings of a ring with a carnelian gem, found on the bank of the Danube, and a golden coin of Emperor Theodosius, found at the site of Rimski grad in 1908. Today, the coin is kept at the National Museum in Belgrade. It is also worth mentioning that fragments of Roman pottery were discovered at the site of Bela Stena (Гарашанин, Д. 1954: 94).

To the east of Bela Stena, the site of Gradine is located, where remains of a Byzantine fortification are present on a dominant plateau. The position of the fort enabled control over a significant portion of the Pannonian plain, made even more important by the fact that the confluence of the rivers Tamiš and Danube is several kilometres to the northeast of the site. We should also mention that Procopius, while writing about Justinian's fortifications on the Danube, mentioned, among others, a strong fort, located some eight miles below Singidunum, and called it Octavus. Ć. Barišić identified that fort as the remains on the site of Gradine. During research on the site of Bela Stena, a team from the Belgrade City Museum performed a field survey at the fort, in the place where the existence of a necropolis was established. On this occasion, four brick built, Roman tombs were discovered (Тодоровић, Кондић и Бирташевић 1956: 77).

The first and the second tomb contained children's skeletons. The first tomb was built out of bricks with dimensions of $44 \times 32 \times 4-8 \mathrm{~cm}$. The length of the tomb was $91 \mathrm{~cm}$, width 35 $\mathrm{cm}$, and height $32 \mathrm{~cm}$. The tomb was oriented along an east-west axis. The skeleton was laid on brick paving, placed on the right side. There were no grave offerings (Тодоровић, Кондић и Бирташевић 1956: 77).

The second tomb was built with bricks, with dimensions of $15 \times 42 \times 9 \mathrm{~cm}$. An almost completely destroyed child's skeleton was found in it, suggesting the possibility that the tomb had been opened and robbed. The tomb was oriented along an east-west axis. There were no grave offerings (Тодоровић, Кондић и Бирташевић 1956: 77).

The third tomb was built of halved tegulae, with dimensions of $41 \times 51 \times 3 \mathrm{~cm}$. The inner width of the tomb was, for the most part, $42 \mathrm{~cm}$, while it reached up to $50 \mathrm{~cm}$ around the head of the deceased. The length of the tomb was $190 \mathrm{~cm}$. There was a skeleton in it, laid on its back, oriented
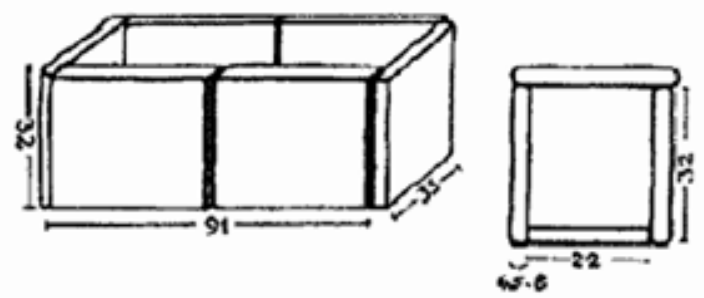

Fig. 2. The construction of a child's tomb at the site of Gradine, near Višnjica, according to: Тодоровић, Кондић и Бирташевић 1956: 77, сл. 5.

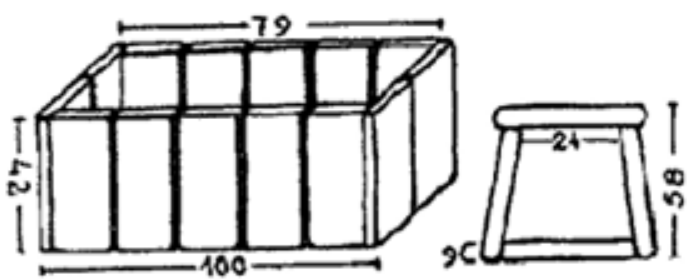

Fig. 3. The construction of a child's tomb at the site of Gradine, near Višnjica, according to: Тодоровић, Кондић и Бирташевић 1956: 77, сл. 6. 
along an east-west axis, with hands crossed on the chest. There were no grave offerings (Тодоровић, Кондић и Бирташевић 1956: 77).

The fourth tomb is similar to the previous ones. It was built with bricks, with dimensions of $44 \times 32 \times 7 \mathrm{~cm}$. On the lateral side, there was a larger tegula with dimensions of $55 \times 43 \times 2.5 \mathrm{~cm}$. The inner dimensions of the tomb are $38 \times 179$ $\mathrm{cm}$. The skeleton was laid on its back, oriented along an east-west axis. The left hand of the deceased was stretched along his body, and the right one placed on his stomach (Тодоровић, Кондић и Бирташевић 1956: 77).

We should also mention that a local, Nikola Urošević, sold several bronze Roman coins to the Belgrade City Museum, which he had found on this site. One piece came from Augustus' coinage, three from Severus Alexander's, of which one is from the city of Nicaea's mintage, one piece from Licinius' coinage, one from Maximian's, and one bronze coin from the period of Jovian's reign (Црнобрња 1978: 205).

During archaeological excavations at the site of Bela Stena, conducted in 1955 by the Belgrade City Museum, numerous fragments of Byzantine and Sarmatian-Iazygian pottery were found in the floor of a bread oven, mixed with Roman pottery fragments, while on the floor of the oven, and around it, fragments of Slav vessels were found (Тодоровић 1958: 329-334).

The findings of gold objects accidentally discovered on a sandbank of the Danube also come from Bela Stena. The findings consists of a gold necklace with a cross and a gold ring. They were discovered among the remains of a skeleton, and most probably come from the necropolis belonging to the Early Byzantine fortification, and are dated to the end of the $6^{\text {th }}$ and the beginning of the $7^{\text {th }}$ century (Татић-Ђурић 1964: 185-193).

There is also data suggesting that remains of an old monastery, which the locals call the monastery of Despot Stefan, exist near Višnjica. Outside of Višnjica, on the bank of the Danube, remains of a circular medieval tower used to be visible (Тодоровић, Кондић и Бирташевић 1956: 88).

There is no direct evidence on the exploitation of hot springs in the area of Višnjička Banja in Antiquity. On the other hand, there's ample proof on the tumultuous life and the existence of a Roman settlement, fort and necropolis in this place, whose development was probably largely influenced by those hot springs.

\section{LEŠTANE}

\begin{tabular}{|c|l|c|l|}
\hline $\begin{array}{c}\text { Bronze Age and Older } \\
\text { Iron Age }\end{array}$ & $\begin{array}{c}\text { The site near Bubanj } \\
\text { Potok } \\
\text { necropolis with skeletal } \\
\text { burials and urns }\end{array}$ & \\
\hline Antiquity & & $\begin{array}{c}\text { The site of Zabran } \\
\text { Accidental finding of an } \\
\text { iron pickaxe }\end{array}$ & \\
\hline Antiquity & & $\begin{array}{c}\text { The site near Bubanj } \\
\text { Potok } \\
\text { pottery }\end{array}$ & \\
\hline
\end{tabular}

Leštane is a settlement in the Municipality of Grocka in the City of Belgrade. There are two hot springs in the area of Leštane, both of which belong to the nitrogenous water group. The temperature of the water at the source of $\mathrm{L}-1$ is $21^{\circ} \mathrm{C}$, and the $\mathrm{pH}$ value 8 , while the temperature at the spring $\mathrm{L}-2$ reaches $25^{\circ} \mathrm{C}$, and the $\mathrm{pH}$ value is also 8 (Филиповић 2003: 76).

During works at the quarry at Leštane, a small cave was discovered and completely destroyed, where, according to the workers, many petrified bones were found, and several hearths. When the 
expert teams arrived in the field, all the findings had already been destroyed, so only several mollusc fossils were gathered. A part of a destroyed hearth was also registered. It is possible that this was a domicile from the Palaeolithic (Бошковић 1956: 11).

During the construction of a by-pass road around Belgrade, at Bubanj Potok, not far from Leštane, workers discovered graves belonging to a prehistoric necropolis. It was recorded that the necropolis was found 5,200 metres from the road to Smederevo. On this occasion, a large number of skeletal graves and urns was dug through. The archaeologists did not manage to arrive in the field in time, hence, they were only able to identify some human bones, fragments of La Tène and Roman pottery and an iron spear. On the basis of the description obtained in the field, the urns could be roughly dated to the period of the Bronze and older Iron Age (Тодоровић, Кондић и Бирташевић 1956: 76).
The only finding from the Antiquity period comes from the site of Zabran, where an Antique pickaxe was found, which is kept in the National Museum in Belgrade today (Поповић, И. 1988: 37).

Findings from Antiquity are too few for us to be able to talk about a horizon at Leštane. The existence of a prehistoric necropolis would suggest a cult place, which could be linked to hot springs. An answer to the questions on the further continuity of this cult place and possible exploitation of hot springs can be given only by future research.

There is a deep shaft with a mineral water spring at Vrdnik Banja. The temperature of water is $33^{\circ} \mathrm{C}$, and the $\mathrm{pH}$ value 7.4 . Within the class of hydro-carbonate waters, it belongs to the magnesium-potassium-calcium subclass, which makes it unique in the region (Филиповић 2003: 111).

The area of Vrdnik abounds with archaeological sites. The oldest traces of settlements come from the multi-layer prehistoric site of Pećine,

VRDNIK

\begin{tabular}{|c|c|c|c|}
\hline Eneolithic & $\begin{array}{l}\text { Vinča culture } \\
\text { Kostolac culture } \\
\text { Vučedol culture }\end{array}$ & $\begin{array}{l}\text { The site of Pećine } \\
\text { settlement } \\
\text { fortification }\end{array}$ & \\
\hline Bronze Age & Bosut culture & $\begin{array}{c}\text { The site of Pećine } \\
\text { settlement } \\
\text { fortification }\end{array}$ & \\
\hline Older Iron Age & & $\begin{array}{l}\text { The site of Pećine } \\
\text { A skeletal grave }\end{array}$ & \\
\hline Antiquity & & Findings of Roman coins & \\
\hline Antiquity & & $\begin{array}{l}\text { The site of Gradište } \\
\text { fortification with a ne- } \\
\text { cropolis (?) }\end{array}$ & \\
\hline Middle Ages & & Fortified city & $\begin{array}{l}11^{\text {th }}-12^{\text {th }} \text { century, } \\
\text { First mentioned in } \\
1315 \text { (Rednak, Red- } \\
\text { nuk, Regnitz). }\end{array}$ \\
\hline Middle Ages & & $\begin{array}{c}\text { Site of Staro Groblje } \\
\text { (Tursko) }\end{array}$ & \\
\hline Late Middle Ages & & $\begin{array}{c}\text { monastery Vrdnik - } \\
\text { Ravanica }\end{array}$ & $\begin{array}{l}\text { End of the } 15^{\text {th }}-\text { be- } \\
\text { ginning of the } 16^{\text {th }} \\
\text { century - first men- } \\
\text { tioned in } 1566\end{array}$ \\
\hline
\end{tabular}


with cultural layers from the Eneolithic, Bronze Age and older Iron Age. There are several known findings of Antique coins in the area of Vrdnik. The Antiquity site of Gradište suggests the possibility that there was a fortification with a necropolis from the Roman period in this place. When it comes to the Middle Ages, we have the fortified city of Vrdnik, mentioned for the first time in 1315. Connected to the city, perhaps, is the oldest part of the multi-layer medieval necropolis at the site of Staro (Tursko) Groblje, where the burial practice continued during the period of the Turkish reign as well. The period of the medieval Vrdnik is concluded with the monastery of Vrdnik - Ravanica, linked by popular myths to Prince Lazar, even though it was built, at the earliest, at the end of the $15^{\text {th }}$ - beginning of the $16^{\text {th }}$ century. The first known mention of the monastery was in 1566.

The multi-layer prehistoric site of Pećine at

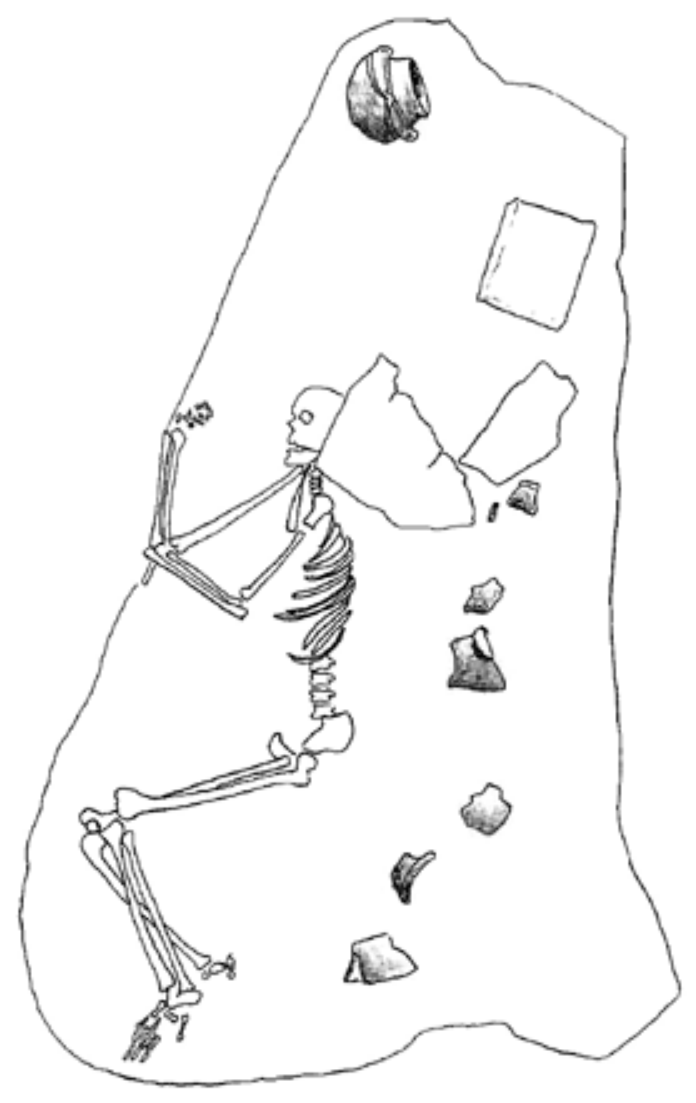

Fig. 4. The sketch of tomb 1 from the site of Pećine at Vrdnik, according to: Медовић 1984/1985: 7, T. I.
Vrdnik was discovered during the systematic research of the territory of Srem, performed in 1967. The dominant position and large amount of mobile archaeological findings indicated that there was a great need to systematically investigate the site. The first archaeological research of the site of Pećine was performed by the Institute for Protection of Cultural Monuments in Sremska Mitrovica in 1969 (Popović, D. i Medović 1969: 35-36).

The site is located on a hill, with three steeply cut sides. The exception is the southern side, where the site is connected, via a long saddle, to the slopes of Fruška Gora. The entrance into the settlement was most probably located on this side (Popović, D. 1981: 13; Медовић 1984/1985: 5; Tasić 1974: 259; Миладиновић-Радмиловић и Капуран 2010: 91).

There was a flattened plateau at the top of the hill, with dimensions of $350 \times 250$ metres, with an artificially made ellipsoid summit. According to the note by D. Popović, the fortification from Vrdnik represents "a typical example of a hillside gradina [hillfort] from Srem" (Popović, D. 1981: 13).

During archaeological research, cultural layers were registered from the Eneolithic, Bronze Age and older Iron Age, i.e. cultural groups of Kostolac, Vučedol, Vinča and Bosut (Ibid; Ibid. 1997: 7; Медовић 1984/1985: 5; МиладиновићРадмиловић и Капуран 2010: 91).

We will single out the only finding from the older Iron Age period - a pit with the remains of a skeletal burial. A skeleton was discovered, laid on the right hip, in a slightly cramped position. The skeleton was oriented along an east-west axis (Медовић 1984/1985: 5-8).

The right arm was bent at an angle of $45^{\circ}$, with the hand at face level, and the left one, also bent at the elbow, with the hand at the height of the right elbow. The knees, set one over another, were found at hip height. The shins were crossed (Поповић, Д. 1997: 9).

The deceased was found below a flat stone of large dimensions. Beside the head of the deceased, as a grave offering, there was an amphora made in 
the manner of the Bosut cultural tradition. Not far from the skeleton, several other pottery fragments were found, decorated with engraved ornaments, from the older Iron Age. It is also interesting to note the findings of a larger vessel, most probably a pithos, decorated with the motive of a fir branch, and a deep bowl, with a garland engraved on the shoulder. P. Medović believes that these fragments could represent the remains of ritually broken vessels (Медовић 1984/1985: 5-8).

Anthropological analysis has shown that the skeletal remains belonged to a male, aged ca 25 at the time of death. Data obtained through the anthropological analysis suggest that this individual most probably died of natural causes (МиладиновићРадмиловић и Капуран 2010: 91-95).

We believe that this type of burial, in which traces of ritual activities can be noted, can be linked to the soteriological function of hot springs.

The site of Gradište is located in the area of Vrdnik, on the plateau of a hill, whose base is ring-shaped. On three sides, the hill slopes have a steep fall, while the only suitable access is on the eastern side. Traces of Antique building material and human bones were registered over a surface area of $100 \times 80 \mathrm{~m}$. Pottery findings are very rare and atypical. The character of the site indicates the existence of a small fortification with a necropolis (Popović, D. 1967: 173).

Findings of Antique coins occurred in the village area (Гарашанин, М. и Гарашанин, Д. 1951: 224; Đorđević 2007: 33).

The site of Staro Groblje or Tursko Groblje is located on the eastern periphery of Vrdnik. Findings of medieval and Turkish pottery were registered, and also one bronze ring, a large amount of human bones and several whole skeletons. It was evidently a medieval necropolis with several burial phases (Popović, D. 1967: 173).

The fortified city of Vrdnik was built at 400 metres above sea level. It was mentioned in historical sources for the first time in 1315 and had been mentioned under different names - Rednak, Rednuk, Regnicz. It had an elongated semi-circular base, with the entrance gate on the eastern part of the rampart. Archaeological excavations demonstrated the existence of walls surrounding the peripheral area as well (Миленковић 1998: 153).

In the village area, there is also the monastery of Vrdnik, dedicated to the Feast of the Ascension of Christ, built at the end of the $15^{\text {th }}$ or the beginning of the $16^{\text {th }}$ century. It was mentioned as "the monastery of Saint John near the village of Vrdnik" in Turkish sources. After the Great Exodus of Serbs in 1690, it was populated by monks from the monastery of Ravanica, and henceforth it is often referred to as the Ravanica of Srem (Кулић и Срећков 1994: 61).

There is a well with mineral water at Slankamen. The temperature of water is $18.4{ }^{\circ} \mathrm{C}$, and the $\mathrm{pH}$ value is 7.5 (Филиповић 2003: 112).

Stari Slankamen represents a very significant multi-layer site. Its complex but, at the same time, clearly differentiated stratigraphy shows traces of settling in the middle and late Bronze Age, Hallstatt, La Tène, through Antiquity, when the city of Acumincum was probably located here, all the way to the late Middle Ages. Most of the findings came from the site of Gradina, although the existence of cultural layers was established at other locations as well.

Two Antiquity layers can be identified at the site of Gradina. The older layer belongs to a Roman settlement, and the more recent to a fortification, i.e. a fortified city, most probably Acumincum. The Antique necropolis, registered at the site of Počenta, is certainly connected to the mentioned settling layers. Findings from Antiquity were also registered at the sites of Dugorep (Humka) and Oduševac, where small fortifications were located, with the function of defending the periphery. In the area of Novi Slankamen, findings from Antiquity were registered at the sites of Grabovac (pottery), Crkvena (bricks), and Pozadina Jande (bronze coins and pottery made in the provincial manner).

$\mathrm{N}$. Tasić provisionally links the horizon from the late Bronze Age at Gradina in Stari Slankamen to the settlement from the Urnfield culture, al- 
though the entire profile of pottery material does, in a certain manner, go beyond the frame of the stylistic properties of the said culture (Тасић 1966: 18).

The site of Venac is located on a high plateau above Gradina and leaves the impression of a prehistoric fortification with a ring-shaped earthen rampart and canals. There are four artificial circular plateaus on the site. A partial examination

\section{SLANKAMEN}

\begin{tabular}{|c|c|c|}
\hline Eneolithic & & $\begin{array}{c}\text { Novi Slankamen, The site of Obala } \\
\text { Potoka } \\
\text { finding of a copper axe }\end{array}$ \\
\hline Middle Bronze Age & & The site of Gradina \\
\hline Late Bronze Age & Urnfield culture & The site of Gradina \\
\hline Older Iron Age & & $\begin{array}{c}\text { Novi Slankamen } \\
\text { The site of Čarevac } \\
\text { hillfort }\end{array}$ \\
\hline La Tène & & $\begin{array}{l}\text { Novi Slankamen, The site of Grabovac } \\
\text { pottery }\end{array}$ \\
\hline La Tène & & $\begin{array}{c}\text { Novi Slankamen } \\
\text { The site of Čarevac } \\
\text { hillfort }\end{array}$ \\
\hline La Tène & & $\begin{array}{l}\text { The site of Gradina } \\
\text { Celtic oppidum } \\
\text { civitas Scordiscorum }\end{array}$ \\
\hline La Tène & & The site of Venac \\
\hline La Tène & & $\begin{array}{c}\text { The site of Tanackov Salaš } \\
\text { pottery }\end{array}$ \\
\hline Antiquity & & $\begin{array}{l}\text { The site of Tanackov Salaš } \\
\text { pottery } \\
\text { stone monument (lost) }\end{array}$ \\
\hline Antiquity & & $\begin{array}{l}\text { The site of Gradina } \\
\text { early roman settlement }\end{array}$ \\
\hline Antiquity & & $\begin{array}{l}\text { The site of Gradina } \\
\text { fortification Acumincum }\end{array}$ \\
\hline Antiquity & & $\begin{array}{l}\text { The site of Dugorep (Humka) } \\
\text { small fortification }\end{array}$ \\
\hline Antiquity & & $\begin{array}{l}\text { The site of Oduševac } \\
\text { small fortification }\end{array}$ \\
\hline Antiquity & & $\begin{array}{l}\text { The site of Počenta } \\
\text { necropolis }\end{array}$ \\
\hline Antiquity & & $\begin{array}{c}\text { Novi Slankamen, The site of Grabovac } \\
\text { pottery }\end{array}$ \\
\hline Antiquity & & $\begin{array}{l}\text { Novi Slankamen, The site of Crkvena } \\
\text { findings of roman bricks }\end{array}$ \\
\hline
\end{tabular}




\begin{tabular}{|c|c|c|c|}
\hline Antiquity & & $\begin{array}{c}\text { Novi Slankamen, The site of Pozadina } \\
\text { Jande } \\
\text { findings of provincial pottery and } \\
\text { bronze coins }\end{array}$ & \\
\hline Middle Ages & $\begin{array}{c}\text { The site of Gradina } \\
\text { fortification }\end{array}$ & $\begin{array}{c}12^{\text {th }}-16^{\text {th }} \\
\text { century }\end{array}$ \\
\hline Middle Ages & $\begin{array}{c}\text { The site of Venac } \\
\text { pottery }\end{array}$ & \\
\hline Middle Ages & & $\begin{array}{c}\text { Novi Slankamen, The site of Crkvena } \\
\text { Findings Of Medieval Materials }\end{array}$ & \\
\hline Middle Ages & $\begin{array}{c}\text { Novi Slankamen, The site of Koševac } \\
\text { hoard of silver coins }\end{array}$ & \\
\hline
\end{tabular}

of one of those showed that they were artificially made. The existence of a stone ring was established, which may have marked the periphery of the plateau. The ring, consisting of a single line of stone, was located some 15 metres from the centre of the plateau. La Tène pottery was found in the lower layers, while fragments of heavily crushed medieval pottery were found near the top. It wasn't possible to determine the purpose of the plateau, that is to say, whether it was a tumulus, sacral object or part of a developed fortification system on the plateau (Dimitrijević i Kovačević 1965: 116).

In the location of today's Slankamen, there was a Celtic oppidum and the Roman fortification of Acumincum. Remains from the La Tène culture indicate that one of the centres of the territory of Scordisci (civitas Scordiscorum) was located here. The La Tène Slankamen certainly had an important role in the military and economic life of the Scordisci. The oppidum at Slankamen was built on a plateau from which the confluence of the Tisa into the Danube, Banat and parts of Bačka were clearly visible (Горенц и Димитријевић 1956: 150-155).

It is certain that the oppidum represented a part, maybe even the central part, of the system of Celtic forts built along the right bank of the Danube, at the presumed mutual distance of seven kilometres. The forts were built over a relatively short time span, almost at the same time, at the end of the $2^{\text {nd }}$ and the first half of the $1^{\text {st }}$ century
ВС (Тапавички-Илић 2014: 21-32).

After the Romans settled in this area, it maintained an autonomy of sorts, even though it nominally belonged to the territory of Bassianae. Inscriptions confirming the existence of Civitas Scordiscorum were found at Slankamen and at Petrovac. The first mentions the princeps and praefectus of the Scoridsci, while the other mentions two brothers, principes, members of the tribal council. Both inscriptions are dated to the end of the $1^{\text {st }}$ and the beginning of the $2^{\text {nd }}$ century AD (Ibid.). The mentioned finding from Slankamen confirms the theory that the settlement of Civitas Scordiscorum was precisely in this place.

The Scordisci forts in eastern Srem continued to exist, and even their Latin names are known. Hence, seven km downstream from Slankamen (Acumincum) there is Surduk, formally Rittium, while $14 \mathrm{~km}$ to the south of it is Novi Banovci, i.e. Burgenae, while $14 \mathrm{~km}$ from Novi Banovci, Zemun (Taurunum) is located. We should also mention that ca seven $\mathrm{km}$ downstream from Zemun is the plateau of Zvezdara, a place which is presumed to have represented the Scordisci oppidum in the area of today's Belgrade, i.e. Roman Singidunum. All the listed forts in eastern Srem were turned into Roman castra, which means that the already existing defence system of the Scordisci was easily fitted into the Roman limes. Wooden structures, palisades and trenches were rebuilt, this time with stone, and within such walls, sol- 


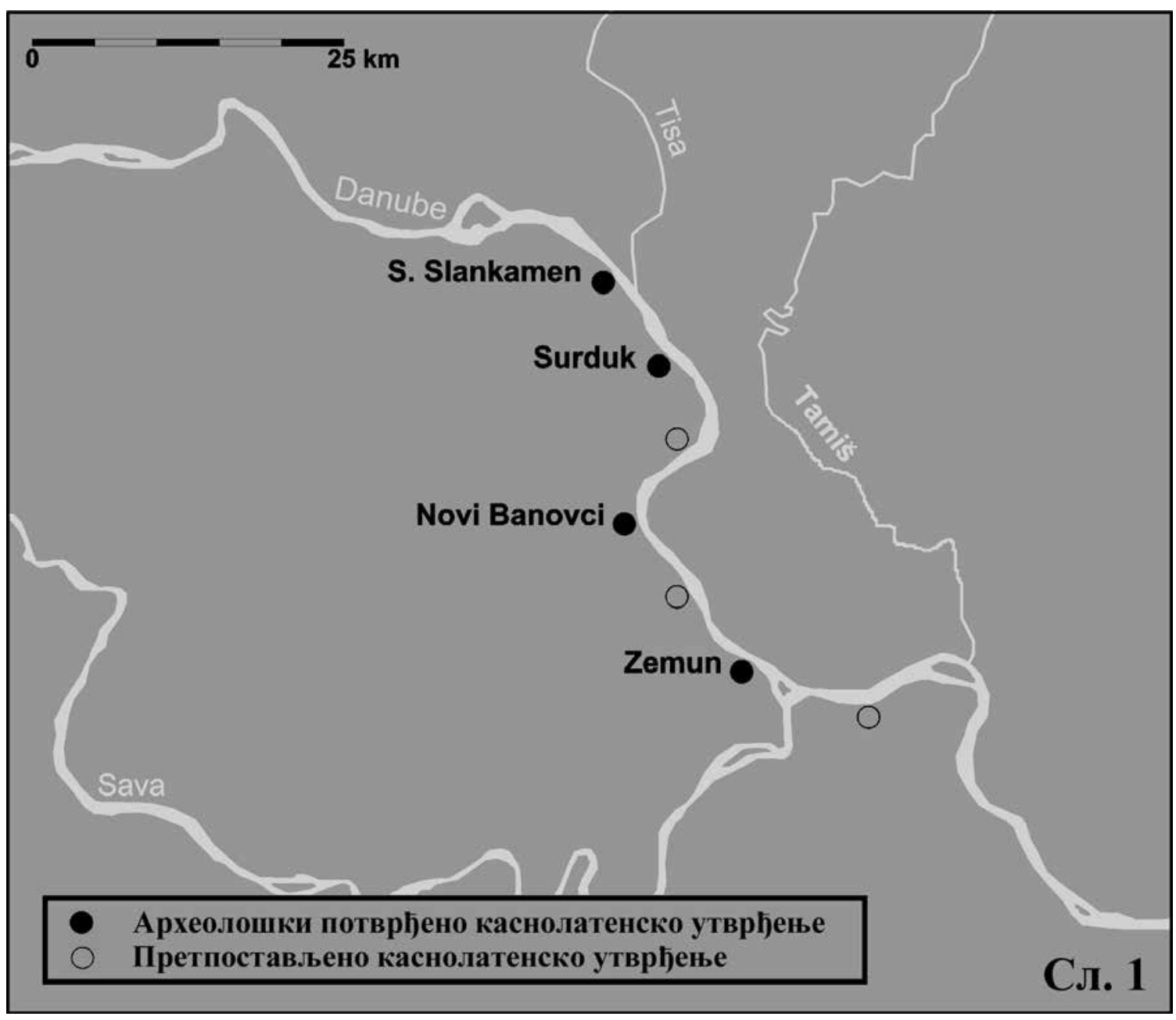

Fig. 5. The position of the oppidum at Stari Slankamen in the presumed system of La Tène fortifications on the right bank of the Danube, according to: Тапавички-Илић 2014: 22, сл. 1.

id constructions were made of stone and brick (Петровић, П. 1995: 18-22).

The best example for the mentioned process of turning Celtic forts into Roman castra is the oppidum at Stari Slankamen, since the Roman castrum matches the Scordisci oppidum completely in size and shape, with both of them fitting into the configuration of the terrain. We know that this fort was restored during the $2^{\text {nd }}-3^{\text {rd }}$ century $A D$. The walls of the fort were built of stone, and within them, new buildings were erected. At the bottom of the plateau there was a civilian settlement, in which a large amount of debris and small findings was discovered (Ibid. 23).

After the Roman conquests, administrative units were formed in the territory of Srem, with a certain amount of autonomy in local matters. We may say that the central territory of the Celtic Scordisci was eastern Srem, while western Srem was populated by the tribes of the Amantini, Breuci, Cornacates and Tricornenses. It is also obvious that the Romans attempted to limit the influence and strength of the most important population within the Scordisci tribe alliance by giving it a limited territory for the future civitas (Jovanović, B. 1987: 850).

Limiting the tribe of Scordisci to the narrow zone of the eastern Danubian valley in Srem was suitable for Roman interests in this part of the Danubian limes. We may assume that there was a fortified settlement in the area designated for the Scordisci civitas, where the most important tribal 


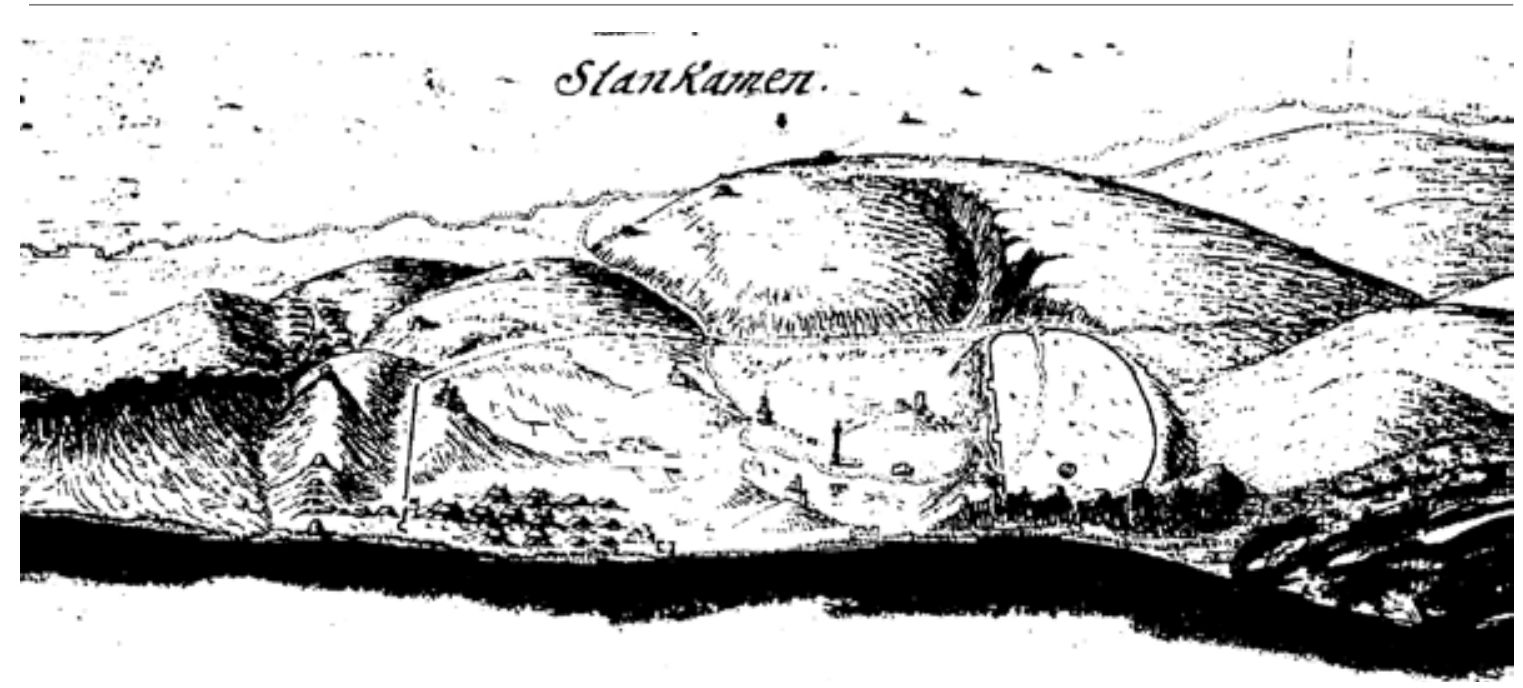

Fig. 6. Marsili's drawing of Slankamen, according to: Popović, M. 1996: 165.

chieftains gathered. Such an organisation ensured at least a partial preservation of old tribal structures (Тапавички-Илић 2014: 30).

A favourable strategic position, on the opposite side from the confluence of the Tisa, caused the early presence of the Roman army in this area. We know that, at the beginning of the $1^{\text {st }}$ century $\mathrm{AD}$, several divisions of the II Adiutrix Legion were stationed in the area of eastern Srem, as well as several auxiliary units. From a later period comes the tombstone of a veteran from the II Adiutrix Legion, discovered near Slankamen. It was, however, only during the reign of Trajan that a large number of forts was built or restored in Pannonia, and troops transferred to the Danube. In this period the Danubian limes got the structure it would retain all the way until the end of the $3^{\text {rd }}$ century AD. During the $2^{\text {nd }}$ century, three auxiliary units were stationed in eastern Srem; among them was the I Campanorum Cohort, stationed at Acumincum (Душанић, С. 1968: 96).

On the opposite bank of the Danube, near Titel, several epigraphic monuments were discovered mentioning the $1^{\text {st }}$ Britannica Cohort. During the late Antiquity period, equestrian units were stationed at Acumincum - cuneus equitum Constantinium Aciminci and equites sagittarii Aciminci (Jovanović, A. 1997: 29-30).

Two bricks with the seal of the $1^{\text {st }}$ Campano- rum Cohort also bear witness to the presence of this unit at Slankamen. One of them, discovered at the end of the $19^{\text {th }}$ century, was transferred to the Archaeological Museum in Zagreb, but it is considered lost today. The other brick, dated into the $2^{\text {nd }}$ or the beginning of the $3^{\text {rd }}$ century, is kept in the archaeological collection of the Belgrade City Museum (Душанић, М. 1988: 87-91).

Bearing witness to the people living in Acumincum, who returned to their homelands after serving their term, is also a tombstone mentioning the $2^{\text {nd }}$ Adiutrix Legion, found on the bank of the Danube, near Slankamen. On the basis of the name of the consuls, Lucius Annius Maximus and Septimius Aper, the monument was dated precisely to 207 AD (Ферјанчић 2002: 266).

Two dominant plateaus can be determined at Stari Slankamen, where the forts may have been located: Gradina and Humka. At the site of Gradina, archaeological excavations registered an Antiquity horizon beneath the medieval fortification. It was probably precisely at the site of Gradina that the antique Acumincum was located.

Research has registered the existence of a luxurious medieval building, dated to the period from the $13^{\text {th }}$ to the $15^{\text {th }}$ century. A large number of stone balls and iron arrows were discovered as well, remnants of the Turkish occupation of the fort. Beneath the foundations of the medieval building, 


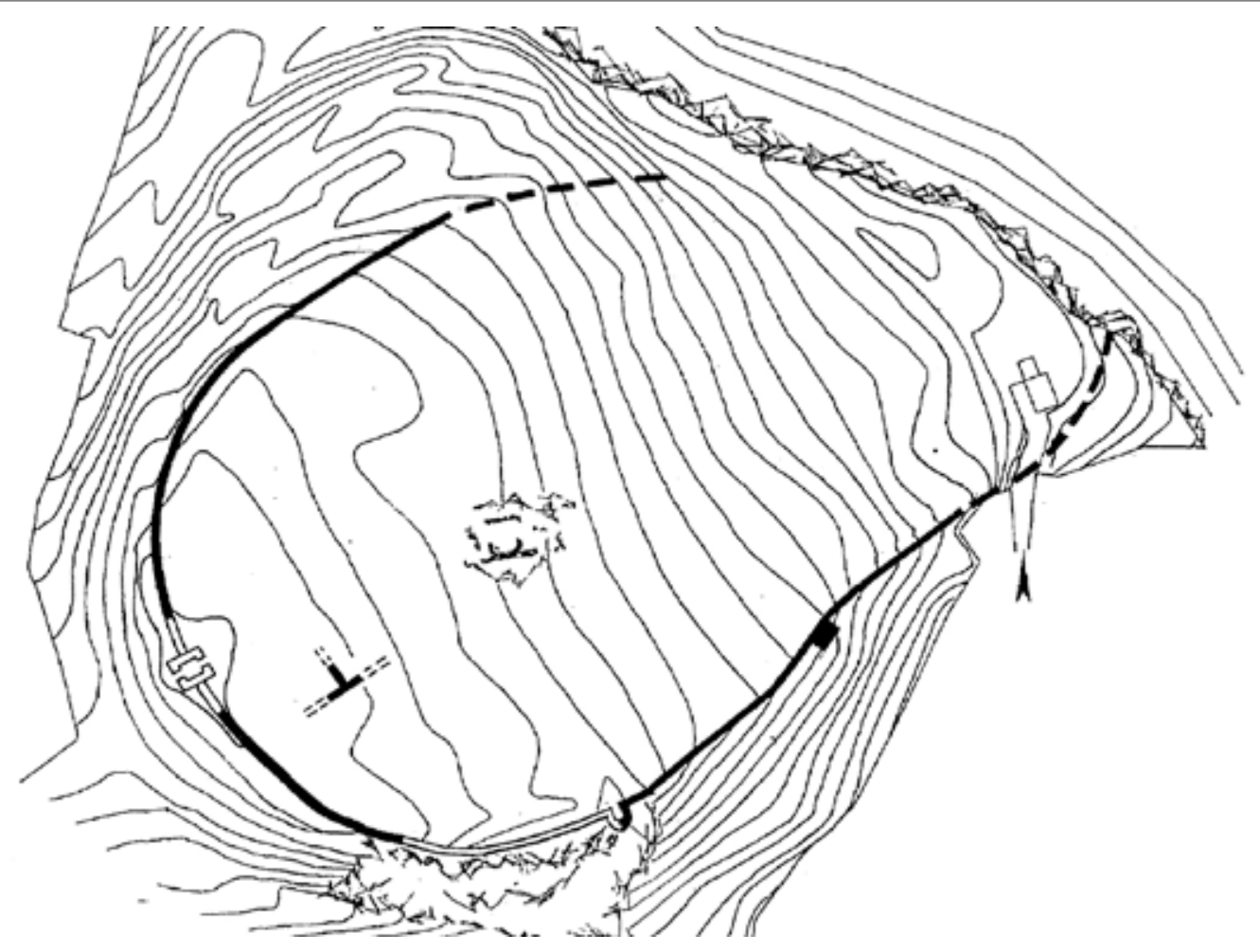

Fig. 7. The fortification at Slankamen, according to: Popović, M. 1996: 165.

a wall from the Antiquity period was discovered, made from crushed and cut stone, joined by mortar. The wall was erected above a prehistoric pit house. It was established that the antique building stretched below the entire medieval object, but it wasn't possible to determine its function. Field surveys have shown that, at the base of Gradina, in the area of today's village, a large civilian settlement had developed, as well as a series of necropoles on the nearby hills. It is probable that a fortification system was built around the periphery as well, traces of which were registered at the sites of Dugorep and Oduševac (Dimtrijević i Kovačević 1965: 116-117).

The important cult centre of Jupiter Dolichenus was at Acumincum, as witnessed by a votive monument discovered in the middle of the $19^{\text {th }}$ century. The altar was transferred to the Kunsthistorisches Museum in Wien in 1851. Lj. Zotović mentions that the Romanisation of the Syrian divinity is clearly visible on the monument, but that some elements of the composition show clear traces of older oriental beliefs and the prototype of the representation of the god Hades, whose Romanised "heir" is Jupiter Dolichenus (Зотовић 1971: 59-64). We believe, however, that there are insufficient elements to link that monument to the cult of Hades.

At the end of the $19^{\text {th }}$ century, J. Brunšmid registered another relief from Slankamen. While staying there, in May 1894, Brunšmid noted a secondarily used marble monument in the ramparts of the city. The author extracted the monument and shipped it to the Archaeological Museum in Zagreb. The monument is decorated with reliefs on two adjacent sides. There is a representation of a palm tree on the wider side, along whose trunk a snake is crawling, while two birds are kissing at the top of the crown. The narrower side of the monument is decorated with a relief representation of a satire. Since the monument was decorated only on those two sides, Brunšmid believes that it was probably a part of a doorpost and suggests that it could have been in a temple of Bacchus (Brunšmid 1895: 182).

In 1954, The Military Museum began its archaeological research of the Danubian limes in 
Srem, in the area from Stari Slankamen to Novi Banovci. In the period from 1955 to 1959, the Military Museum performed archaeological excavations on the site (Peković 2013: 13-14). In 1955, the National Museum from Zemun took part in research on the site of Gradina.

In the area of Roman Acumincum, the existence of prehistoric, antique and medieval cultural layers was registered. The north-eastern slope of Gradina was especially intensely populated in the Roman period, when it had a defence function on the line of the Danubian limes.

A plateau of a predominantly loess composition, at the site of Gradina, is dominated by the remains of a medieval city. Archaeological research has shown that the medieval ramparts continue onto the Roman walls and follow their trajectory. Two phases of Roman settlements were registered: an early Roman settlement, formed during the reign of the Flavian dynasty, and a fortified Roman settlement, with massive mortared walls, with abundant monetary findings from the $4^{\text {th }}$ century (Đorđević 2007: 72-73).

The site of Humka or Dugorep is located at the confluence of the Tisa and the Danube, some 30-40 metres above the steep right bank of the Danube. Archaeological research conducted in 1958 showed the existence of a fortified object speculum, with dimensions of $7.75 \times 7.75 \mathrm{~m}$. On the basis of the manner in which it was built and the mobile findings, the object was dated into the $4^{\text {th }}$ century. At the site of Tanackov Salaš, during a field survey, the existence of La Tène pottery was registered, as well as early Roman pottery of provincial crafting. The existence of a Roman monument, with an inscription, was also established. Unfortunately, we were unable to find more precise data on this inscription (Ibid. 73).

The medieval Slankamen is listed as "urbs" (ad urbem Slankemun) as early as 1189, when mentioned by Arnold of Lübeck. An even more important piece of information comes from 1442, when a letter from the Chapter of Budim mentions Slankamen as "castrum ac oppidum". The existence of the city - the fortification and the periphery - and its suburb is mentioned in 1553 by Antun Vrančić in his travel log, which states that Slankamen had "arx et oppidum". In the $16^{\text {th }}$ century, Slankamen is mentioned by two other travellers, Stevan Gerlah in 1573 and Vratislav in 1591. Both these authors noted that there was a city in Slankamen and its suburb, surrounded by walls, but they were all in ruins in their time already. The Turks took and destroyed the city in 1521 for the first time, finally conquering it in 1526 . In a letter from the nuncio of Budim, Baro de Borgia, from the same year, there is a mention of the Sultan staying at Slankamen and raising fortifications. When it comes to the objects from the city, written sources mention only four of them - the cathedral of the Holy Spirit with a hospital for the poor and invalids, raised by Jovan Man between 1316 and 1334, the church of Saint Mary, mentioned for the first time in 1400, the orthodox church of Saint Nicholas, traditionally linked to Zmaj Ognjeni Vuk, and the city gate (Dimitrijević i Kovačević 1965: 118).

In the area of Stari Slankamen, at the site of Počenta, the existence of a Roman necropolis was registered, certainly connected to the antique Acumincum (Popović, D. 1967: 178).

The accidental finding of a bronze axe from the Eneolithic period comes from the area of Novi Slankamen. The axe is kept in the Heritage Museum of Ruma today (Велимировић 2009: 9).

The site of Čarevac is located some $1.5 \mathrm{~km}$ from the periphery of Novi Slankamen. It is located on an oval hill, with a very favourable strategic position. It is a hill fort from the Hallstatt and La Tène period, whose three sides are free, and is separated from the adjoining hill by a small trench on the southern side (Popović, D. 1969: 251).

One kilometre from the northwest of Novi Slankamen is the site of Grabovac, where fragments of La Tène and Roman pottery were registered. The site of Crkvena is located on the northern periphery of the settlement, near today's cemetery. It is on a hill in the shape of a rounded square, with dimensions of $70 \times 70 \mathrm{~m}$. There are 
very rare traces of Roman brick on the surface, as well as more numerous findings of slag, bones and roughly-made medieval pottery. The configuration of the terrain indicates that this could have been a fortification, while local tradition has it that there was a mosque in this place. In the area of Kruševac, in the 1970s, a hoard of medieval silver coins was found (Popović, D. 1969: 252).

Also originating from Novi Slankamen is the finding of a drachma from the Greek city of Dyrrhachion (Brunšmid 1912, 265). On the site of Pozadina Jande, the existence of fragments of Roman pottery of provincial crafting was established, as well as Roman bronze coins (Đorđević 2007: 73).

Exceptional strategic advantages have always been the dominant reason for choosing Slankamen as the location for building a fort which would dominate and have control over a wide area. However, the toponym itself clearly indicates that the people were well aware of the properties given to this place by the existence of mineral springs. It is very probable that, during different periods of time, Antiquity included, the springs of Slankamen were exploited by the local population. The confirmed antique cults, that of Jupiter Dolichenus and, probably, Bacchus, cannot be linked directly to healing sources, but we may assume that there will be findings linked to iatric cults in future research on this site.

A system of accumulative lakes was constructed on the southern slopes of Fruška Gora, in the area from Sot to Maradik. The largest of those lakes, with a length of 4.5 kilometres, is located near Erdevik, in the valley of Moharač. In the surroundings of Erdevik, and especially in the area of Banja Kulina, there are several hot springs.

In the vicinity of the lake, remains of a prehistoric settlement were researched. The site is located ca 2,200 metres to the northeast of the centre of Erdevik, in the area of Lica (more precisely, Gornja Lica). It is located on an elevated terrace. The rough dimensions of the site are $500 \times 200$ metres. The prehistoric settlement was developed in hori- zontal stratigraphy, and buildings were set at large distances. A field survey on the site was conducted in 1980, with rescue archaeological excavations in the following year (Поповић, Д. 1995/1996: 7).

Archaeological research has shown that this prehistoric settlement was inhabited in the Eneolithic period, within the cultural frame of the Baden and Kostolac groups, as witnessed by pottery findings. Flint and bone material tools are few. On the other hand, unprocessed remains of animal bones are very numerous, which would indicated that husbandry and hunting had a more dominant economic role in this settlement than farming. From metal findings, a needle with a biconical head was found (Поповић, Д. 1995/1996: 11-12).

Discovered immobile objects were most frequently found as forms dug into the virgin soil, which can most probably be defined as pits. Only in one case was it a pit house, in which there was a partially preserved oven. Also, the existence of a house above the ground was registered, only in one case, with a partially preserved, coated floor. On this site, smaller pieces of the flooring, as well as house daub and wattle were found, which indicates that there were other objects built above the ground as well. Dug-in objects of the pit house type belong to the Baden group, while the objects built above the ground are linked to the Kostolac group. D. Popović puts the prehistoric settlement of Erdevik into the group of "fortified cities from Fruška Gora", as a simpler type, in which traces of earthen fortifications are not abundantly present. This type of settlement is represented by several dozen sites on the southern slopes of Fruška Gora and on high loess terraces of the Danube (Поповић, Д. 1995/1996: 11-13).

The site of Selište is located on the periphery of Erdevik, on a hill through which a stream is running. On the side facing the valley, the hill has a steep fall, while the other three sides are at more or less the same height as the surrounding area. A small hoard of bronze objects found on this site is kept at the Museum of Srem in Sremska Mitrovica. Chronologically speaking, the hoard belongs to Hallstatt 


\section{ERDEVIK}

\begin{tabular}{|c|c|c|l|}
\hline Eneolithic & $\begin{array}{c}\text { Baden and Kosto- } \\
\text { lac group }\end{array}$ & settlement, hillfort & \\
\hline Older Iron Age & $\begin{array}{c}\text { Hallstatt B - C, } \\
\text { with Thraco-Cim- } \\
\text { merian elements }\end{array}$ & $\begin{array}{c}\text { the site of selište } \\
\text { hoard of metal objects }\end{array}$ & \\
\hline Older Iron Age & Iron Age II & $\begin{array}{c}\text { the site of selište } \\
\text { settlement }\end{array}$ & \\
\hline Antiquity & & $\begin{array}{c}\text { the site of kulina } \\
\text { bathing pool }\end{array}$ & \\
\hline
\end{tabular}

B-C, and it also contains some Thraco-Cimmerian elements (Vinski i Vinski-Gasparini 1956: 90).

During the field survey, performed by the Institute for Protection of Cultural Monuments in Sremska Mitrovica, in 1972, mobile archaeological material was registered on the surface. The material indicates the existence of a multi-layer prehistoric settlement, also including a cultural layer from the older Iron Age, dated to the period of the Iron Age II. The findings are kept at the Museum of Srem in Sremska Mitrovica (Popović, D. 1981: 17).

The existence of Roman ruins at Erdevik was registered in the $18^{\text {th }}$ century, more specifically in 1798 , when it was noted that, not far from the settlement (in the direction of the village of Divoš), there were some remains of a Roman building complex with ramparts, arches and pillars (Сремац 2014: 10). The toponym Banja (spa) at Erdevik was noted a bit earlier, more precisely, in 1736 , hence, we may assume that there was a bath, a healing spring or a spa resort. Also in this vein is the toponym of Toplice (again, spa). It is interesting to note the toponym Male Kalile as well, deriving from the Turkish word denoting a place where water can be found even during droughts, which indicates the possibility of a settlement formed near a regular water spring (Сремац 2008: 318).

In 1982, the Museum of Srem conducted archaeological excavations at the site of Banja Kulina near Erdevik, a small lake with several hot springs, converted into a spa by the Romans. The site was registered during works to widen the lake, and inlay it with stone. On this occasion, a Roman wall was discovered, after which archaeological research followed.

The existence of five walls was registered on the site, as well as two building phases. One wall belongs to a more recent building phase, while the remaining four form a vast pool, oriented along a north-eastern to south-western axis. The walls are 12.5 metres long, and the largest width is 2.90 $\mathrm{m}$. They were made of brick, joined with mortar. The room represents a part of a larger complex. The eastern and the southern walls were dividing walls, while the western and the northern ones bore the roof construction. In the corners of the pool, a wooden, grill-like construction was discovered. The object is dated to the $3^{\text {rd }}-4^{\text {th }}$ century (Radenović-Pejović 1985: 108).

Two fragments of plumbing pipes and an iron nail were found. In the pool and its immediate vicinity there are several hot springs, hence, it is believed that the Romans may have used it as a spa bath. Mobile archaeological material was registered in the immediate vicinity, including coins minted during the reign of Antoninus Pius, as well as the remains of two built tombs. A. Jovanović notes that, according to the data from the archive of the Museum of Srem, arms (spears) were found in the tombs, which is why they are classified into the late Antiquity grave type - with tools and arms, connected to foreign funerary elements. Analogies for this construction were found at Varaždinske Toplice, at the site of Aquae Iasae (Radenović-Pejović 1985: 109; Đorđević 2007: 31; Јовановић, А. 1994: 123). 


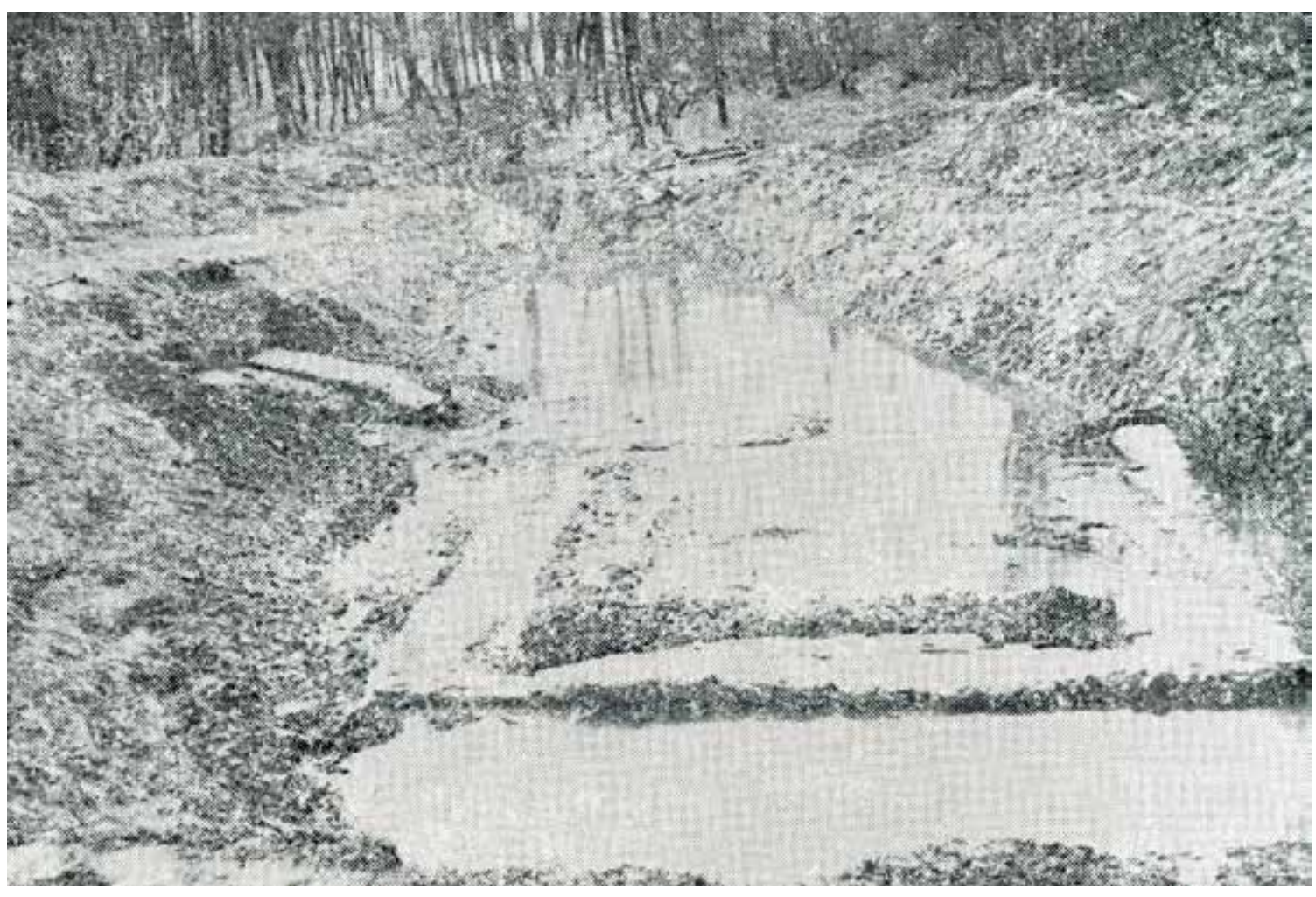

Fig. 8. The pool at Banja Kulina, near Erdevik, according to: Radenović Pejović 1985: T. LVI, sl. 1.

This overview of sites and findings suggests the possibility that the mentioned hot springs were known of and used during Antiquity. It is the task of future research, both in the field and in theory, to find more specific evidence to definitely confirm this highly substantiated supposition.

$$
* * *
$$

Arheologija i prirodne nauke (Archaeology and Science) is an Open Access Journal. All articles can be downloaded free of charge and used in accordance with the licence Creative Commons

- Attribution-NonCommercial-NoDerivs 3.0 Serbia (https://creativecommons.org/licenses/bync-nd/3.0/rs/.

Časopis Arheologija i prirodne nauke je dostupan u režimu otvorenog pristupa. Članci objavljeni u časopisu mogu se besplatno preuzeti sa sajta i koristiti u skladu sa licencom Creative Commons - Autorstvo-Nekomercijalno-Bez prerada 3.0 Srbija (https://creativecommons.org/licenses/bync-nd/3.0/rs/.

\section{BIBLIOGRAPHY}

\section{Бошковић, Ћ. 1956}

Археолошки споменици и налазишта у Србији - II Централна Србија, Београд: Научна књига. (Bošković, Đ. 1956

Arheološki spomenici i nalazišta u Srbiji - II Centralna Srbija, Beograd: Naučna knjiga.)

\section{Brunšmid, J. 1895}

Arheološke bilješke iz Dalmacije i Panonije, Vjesnik Hrvatskog arheološkog društva (n. s.) I: 148-183.

\section{Црнобрња, Н. 1978}

Попис и карта налаза античког новца на подручју града Београда, Годишњак Града Београда XXV: 97-210.

(Crnobrnja, N. 1978

Popis i karta nalaza antičkog novca na području grada Beograda, Godišnjak Grada Beograda XXV: 97-210.) 


\section{Dimitrijević, D. i Kovačević, J. 1965}

Stari Slankamen (Acumincum), Inđija - praistorijska, antička i srednjovekovna nalazišta, Arheološki pregled (Beograd) 7: 115-120.

\section{Душанић, М. 1988}

Римске опеке са жигом са панонског лимеса (одсек Cuccium - Taurunum), Старинар (н. с.) XXXIX: 85-98.

(Dušanić, M. 1988

Rimske opeke sa žigom sa panonskog limesa (odsek Cuccium - Taurunum), Starinar (n. s.) XXXIX: 85-98.)

\section{Душанић, С. 1968}

Римска војска у источном Срему, Зборник Филозофског факултета (Београд) X-1: 87-113.

(Dušanić, S. 1968

Rimska vojska u istočnom Sremu, Zbornik Filozofskog fakulteta (Beograd) H-1: 87-113.)

\section{Đorđević, M. 2007}

Arheološka nalazišta rimskog perioda u Vojvodi$n i$, Beograd: Republički zavod za zaštitu spomenika kulture.

\section{Ерцеговић-Павловић, С. 1969}

Остава наушница са римско-византијског кастела из Бољетина на Дунаву, Старинар (н. с.) XX: 83-95.

(Ercegović-Pavlović, S. 1969

Ostava naušnica sa rimsko-vizantijskog kastela iz Boljetina na Dunavu, Starinar (n. s.) XX: 83-95.)

\section{Ерцеговић-Павловић, С. 1982/1983}

Бољетин, средњовековно насеље и некропола, Старинар (н. с.) XXXIII-XXXIV: 225-229.

(Ercegović-Pavlović, S. 1969

Ostava naušnica sa rimsko-vizantijskog kastela iz Boljetina na Dunavu, Starinar (n. s.) XX: 83-95.)

Ферјанчић, С. 2002

Насељавање легијских ветерана у балканским провиниијама I-III век н. е., Београд: Балкано- лошки институт.

(Ferjančić, S. 2002

Naseljavanje legijskih veterana u balkanskim provincijama I-III vekn. e., Beograd:Balkanološki institut.)

\section{Филиповић, Б. 2003}

Минералне, термалне и термоминералне воде Србије, Врњачка Бања: Удружење бањских и климатских места, Врњачка Бања и Београд: Институт за хидрогеологију Рударско-геолошког факултета у Београду.

(Filipović, B. 2003

Mineralne, termalne $i$ termomineralne vode Srbije, Vrnjačka Banja: Udruženje banjskih i klimatskih mesta, Vrnjačka Banja i Beograd: Institut za hidrogeologiju Rudarsko-geološkog fakulteta u Beogradu.)

\section{Гарашанин, Д. 1954}

Археолошки споменици у Београду и околини, Годишњак Града Београда I: 45-98.

(Garašanin, D. 1954

Arheološki spomenici u Beogradu i okolini, Godišnjak Grada Beograda I: 45-98.)

Гарашанин, М. и Гарашанин, Д. 1951

Археолошка налазишта у Србији, Београд: Просвета.

(Garašanin, M. i Garašanin, D. 1951

Arheološka nalazišta u Srbiji, Beograd: Prosveta.)

\section{Горенц, М. и Димитријевић, Д. 1956}

„Градина“ у Старом Сланкамену, Рад војвођанских музеја 5: 150-155.

(Gorenc, M. i Dimitrijević, D. 1956

„Gradina“ u Starom Slankamenu, Rad vojvođanskih muzeja 5: 150-155.)

\section{Јовановић, А. 1994}

О проблему касноантичких гробова с оружјем на тлу Србије, Зборник Народног музеја (Београд) XV -1: 119-132.

(Jovanović, A. 1994 
O problemu kasnoantičkih grobova s oružjem na tlu Srbije, Zbornik Narodnog muzeja (Beograd) XV -1: 119-132.)

\section{Jovanović A. 1997}

Akuminkum, u: Arheološki leksikon, D. Srejović (ur.), Beograd: Savremena administracija, 29-30.

\section{Jovanović B. 1987}

Keltska kultura u Jugoslaviji. Uvod i Istočna grupa, u: Praistorija jugoslavenskih zemalja V, A. Benac (ur.), Sarajevo: Akademija nauka i umjetnosti Bosne i Hercegovine i Centar za balkanološka ispitivanja, 815-854.

\section{Каниц, Ф. 1985}

Србија земља и становништво - од римског доба до краја XIX века, прва књига, Београд: Српска књижевна задруга и ИРО Рад.

(Kanic, F. 1985

Srbija zemlja i stanovništvo - od rimskog doba do kraja XIX veka, prva knjiga, Beograd: Srpska književna zadruga i IRO Rad.)

\section{Каниц, Ф. 1989}

Србија земьва и становниттво - од римског доба до краја XIX века, друга књига, Београд: Српска књижевна задруга - ИРО Рад.

(Kanic, F. 1989

Srbija zemlja i stanovništvo - od rimskog doba do kraja XIX veka, druga knjiga, Beograd: Srpska književna zadruga - IRO Rad.)

\section{Кондић, В. 1971}

Cantabaza, Smorna, Campsa, Старинар (н. с.) XXXII: 53-58.

(Kondić, V. 1971

Cantabaza, Smorna, Campsa, Starinar (n. s.) XXXII: 53-58.)

\section{Кулић, Б. и Срећков, Н. 1994}

Манастири Фрушке Горе, Нови Сад: Покрајински завод за заштиту споменика културе.

(Kulić, B. i Srećkov, N. 1994
Manastiri Fruške Gore, Novi Sad: Pokrajinski zavod za zaštitu spomenika kulture.)

\section{Медовић, П. 1984/1985}

Скелетни гроб старијег гвозденог доба са локалитета Пећине у Врднику, Гласник Музеја Војводине 29: 5-8.

(Medović, P. 1984/1985

Skeletni grob starijeg gvozdenog doba sa lokaliteta Pećine u Vrdniku, Glasnik Muzeja Vojvodine 29: 5-8.)

Миладиновић-Радмиловић, Н. и Капуран, A. 2010

Антрополошка анализа налаза из гроба откривеног на локалитету Пећине у Врднику, Рад Музеја Војводине 52: 91-99.

(Miladinović-Radmilović, N. i Kapuran, A. 2010 Antropološka analiza nalaza iz groba otkrivenog na lokalitetu Pećine u Vrdniku, Rad Muzeja Vojvodine 52: 91-99.)

\section{Миленковић, М. 1998}

Врдник, Утврђење, Споменичко наслеђе Србије - непокретна кулурна добра од изузетног и великог значаја, Светлана Пејић (ур.), Београд: Републички завод за заштиту споменика културе, 153.

(Milenković, M. 1998

Vrdnik, Utvrđenje, Spomeničko nasleđe Srbije nepokretna kulurna dobra od izuzetnog $i$ velikog značaja, Svetlana Pejić (ur.), Beograd: Republički zavod za zaštitu spomenika kulture, 153.)

\section{Milošević, P. i Jeremić, M. 1986}

Le castellum à Milutinovac, Бердапске свеске III: 245-263.

(Milošević, P. i Jeremić, M. 1986

Le castellum à Milutinovac, Đerdapske sveske III: 245-263.)

\section{Peković, M. 2013}

Archaeological Research of the Military Museum from 1954 - 2012, Весник Војног музеја 40: 11-27. 
(Peković, M. 2013

Archaeological Research of the Military Museum from 1954 - 2012, Vesnik Vojnog muzeja 40: 1127.)

\section{Петровић, П. 1995}

Римски лимес на Дунаву у Доњој Панонији, у: Фрушка Гора у античко доба (Прилози за ста-

ру историју и археологију), Никола Тасић (ур.), Нови Сад: Матица српска, 9-32.

(Petrović, P. 1995

Rimski limes na Dunavu u Donjoj Panoniji, u: Fruška Gora u antičko doba (Prilozi za staru istoriju i arheologiju), Nikola Tasić (ur.), Novi Sad: Matica srpska, 9-32.)

\section{Popović, D. 1967}

Rekognosciranja u Sremu, Arheološki pregled (Beograd) 9: 172-180.

\section{Popović, D. 1969}

Rekognosciranje u Sremu, Arheološki pregled (Beograd) 11: 249-259.

\section{Popović, D. 1981}

Keramika starijeg gvozdenog doba u Sremu, Beograd: Savez arheoloških društava Jugoslavije i Sremska Mitrovica: Zavod za zaštitu spomenika kulture u Sremskoj Mitrovici.

\section{Поповић, Д. 1995/1996}

Истраживање праисторијског насеља „Лице“ у Ердевику, Рад Музеја Војводине 37-38: 7-26. (Popović, D. 1995/1996

Istraživanje praistorijskog naselja „Lice“ $u$ Erdeviku, Rad Muzeja Vojvodine 37-38: 7-26.)

Поповић, Д. 1997

Истраживање локалитета (Пећине) у Врднику, Рад Музеја Војводине 39: 7-40.

(Popović, D. 1997

Istraživanje lokaliteta (Pećine) u Vrdniku, Rad Muzeja Vojvodine 39: 7-40.)

\section{Popović, D. i Medović, P. 1969}

Pećine, Vrdnik - naselje eneolitskog i ranog bronzanog doba, Arheološki pregled (Beograd) 11: 35-36

\section{Поповић, И. 1988}

Античко оруђе од гвожђа у Србији, Београд: Народни музеј.

(Popović, I. 1988

Antičko oruđe od gvožđa u Srbiji, Beograd: Narodni muzej.)

\section{Popović, M. 1996}

La forteresse de Slankamen, Старинар (н. с.) XLVII: 155-168.

(Popović, M. 1996

La forteresse de Slankamen, Starinar (n. s.) XLVII: 155-168.)

\section{Radenović-Pejović, Z. 1985}

Banja Kulina, Erdevik - rimsko kupatilo, Arheološki pregled (Beograd) 24: 108-109.

\section{Сремац, Р. 2008}

Прилог познавању топонима општине Шид са посебним освртом на римске локалитете, Гласник Српског археолошког друштва 24: 313-328. (Sremac, R. 2008

Prilog poznavanju toponima opštine Šid sa posebnim osvrtom na rimske lokalitete, Glasnik Srpskog arheološkog društva 24: 313-328.)

\section{Сремац, Р. 2014}

Извори из XVIII и XIX века за проучавање археолошке баштине општине Шид, Грађа за проучавање споменика културе Војводине XXVII, 7-16.

(Sremac, R. 2014

Izvori iz XVIII i XIX veka za proučavanje arheološke baštine opštine Šid, Građa za proučavanje spomenika kulture Vojvodine XXVII, 7-16.)

\section{Тапавички-Илић, М. 2014}

Фортификациони систем Скордиска, Крушевачки зборник 16, 21-32. 
(Tapavički-Ilić, M. 2014

Fortifikacioni sistem Skordiska, Kruševački

zbornik 16, 21-32.)

Тасић, Н. 1966

Проблем културе поља са урнама у Војводини, Старинар (н. с.) XVII, 15-26.

(Tasić, N. 1966

Problem kulture polja sa urnama u Vojvodini, Starinar (n. s.) XVII, 15-26.)

Tasić, N. 1974

Starije gvozdeno doba, u: Praistorija Vojvodine, P. Popović (ur.), Novi Sad: Institut za izučavanje istorije Vojvodine i Savez arheoloških društava Jugoslavije, 257-276.

\section{Татић-Ђурић, М. 1964}

Златни налаз из Вишњице, Зборник Народног музеја (Београд) IV: 185-195.

(Tatić-Đurić, M. 1964

Zlatni nalaz iz Višnjice, Zbornik Narodnog muzeja (Beograd) IV: 185-195.)

\section{Тодоровић, J. 1958}

Ранословенске пећи код Вишњице, Старинар (н. с.) VII-VIII: 329-334.

(Todorović, J. 1958

Ranoslovenske peći kod Višnjice, Starinar (n. s.) VII-VIII: 329-334.)

Тодоровић, Ј., Кондић, В. и Бирташевић М. 1956

Археолошка налазишта у Београду и околини, Годишњак Града Београда III: 75-98.

(Todorović, J., Kondić, V. i Birtašević M. 1956

Arheološka nalazišta u Beogradu i okolini, Godišnjak Grada Beograda III: 75-98.)

\section{Велимировић, С. 2009}

Нове бакарне секире и дуго длето из источног Срема, Зборник Завичајног музеја Рума VI: 7-20. (Velimirović, S. 2009

Nove bakarne sekire i dugo dleto iz istočnog Sre- ma, Zbornik Zavičajnog muzeja Ruma VI: 7-20.)

Vinski, Z. i Vinski-Gasparini, K. 1956

Prelagomena k statistici i kronologiji prethistorijskih ostava u Hrvatskoj i u vojvođanskom području Srijema, Opuscula Archaeologica I: 57-90.

Вулић, Н. 1909

Антички споменици наше земље, Гласник Српске краљевске академије 47/40, 109-191.

(Vulić, H. 1909

Antički spomenici naše zemlje, Glasnik Srpske kraljevske akademije 47/40, 109-191.)

Зотовић, Љ. 1971

Ново тумачење Долихеновог споменика из Сланкамена, Старинар (н. с.) XXII: 59-66.

(Zotović, LJ. 1971

Novo tumačenje Dolihenovog spomenika iz Slankamena, Starinar (n. s.) XXII: 59-66.)

Зотовић, Љ. 1982/1983

Бољетин (Smorna), римски и рановизантијски логор, Старинар (н. с.) XXXIII-XXXIV: 212-225. (Zotović, LJ. 1982/1983

Boljetin (Smorna), rimski i ranovizantijski logor, Starinar (n. s.) XXXIII-XXXIV: 212-225.)

\section{REZIME}

\section{ANTIČKI ARHEOLOŠKI} LOKALITETI REGISTROVANI

U OKRUŽENJU TERMALNIH IZVORA DUŽ DUNAVSKOG LIMESA U SRBIJI

KLJUČNE REČI: LIMES, DUNAV, ARHEOLOŠKI LOKALITETI, TERMALNI IZVORI, ANTIKA, SRBIJA, MILUTINOVAC, BOLJETIN, VIŠNJIČKA BANJA, LEŠTANE, VRDNIK, SLANKAMEN, ERDEVIK.

Duž rimskog limesa (deo u sastavu današnje Srbije) postoji više termalnih izvora. Pored nekih od njih registrovani su arheološki lokaliteti koji 
ukazuju na mogućnost korišćenja termalnih izvora u antičkom periodu. U radu su predstavljeni lokaliteti i nalazi pronađeni u okruženju termalnih izvora u Milutinovcu, Boljetinu, Višnjičkoj Banji, Leštanima, Vrdniku, Slankamenu i Erdeviku.

U Milutinovcu, na mestu gde je dunavski Ključ najuži, nalazilo se ranovizantijsko utvrđenje, uslovno identifikovano sa Timenom, zabeleženom kod Prokopija. Kanic navodi da se na ovom mestu nalazio izvor „prilično ukusne tople slane vode“.

$\mathrm{Na}$ prostoru Boljetina postojao je vojni logor, korišćen od I do VI veka, pri čemu je dva puta obnavljan (u III i VI veku). Moguće je njegovo identifikovanje sa Smornom, zabeleženom kod Prokopija. U okviru utvrđenja konstatovano je postojanje rimskog kupatila, nad kojim je podignut hrišćanski verski objekat. Pronađena je i nekropola iz XII-XIV veka, u okviru čijeg istraživanja je utvrđeno i postojanje rimskih grobova, kaom i ostava nakita iz X-XI veka.

Na prostoru Boljetina konstatovano je postojanja vojnog logora, korišćenog od I do VI veka. Izgrađen je u prvoj polovini I veka, kao zemljano utvrđenje sa palisadama. Tokom druge polovine I veka podignuti su zi-dani bedemi. Utvrđenje je u II veku, možda za vreme Hadrijanove vladavine, napušteno. Prvi put je obnov-ljeno neposredno pred Aurelijanovo napuštanje Dakije. Razrušeno je u velikom požaru tokom prvih decenija $\mathrm{V}$ veka. Po drugi put je obnovljeno za vreme velike Justinijanove obnove u VI veku.

Najstariji nalazi sa prostora Višnjice i Višnjičke Banje potiču iz perioda metalnih doba. Brojni su nalazi koje svedoče o životu u antici - nakit, novac, votivni natpisi, antefiksi, zidane grobnice, a možda i manja fortifikacija. Nesumnjivi su ostaci ranovizantijskog utvrđenja na lokalitetu Gradine, koji se možda može identifikovati sa Octavumom, koji pominje Prokopije. Poznati su i nalazi slovenskih peći, dok srednjovekovni ostaci i predanje ukazuju na postojanje kružne kule i manastira.

Antički nalazi su malobrojni da be se moglo govoriti o horizontu u Leštanima. Postojanje praistorijske nekropole ukazuje na kultno mesto, mo- guće povezano sa termalnim izvorima. O daljem kontinuitetu ovog kultnog mesta i eventualnoj eksploataciji termalnih izvora, odgovor mogu dati samo buduća istraživanja.

Prostor Vrdnika obiluje arheološkim lokalitetima. Najstariji tragovi naseljavanja potiču sa višeslojnog praistorijskog nalazišta Pećine, sa slojevima iz eneolita, bronzanog doba i starijeg gvozdenog doba. Iz atara Vrdnika poznato je više nalaza antičkog novca. Antički lokalitet Gradište ukazuje na mogućnost da se na ovom mestu nalazilo utvrđenje sa nekropolom. Iz epohe srednjeg veka imamo utvrđeni grad Vrdnik, čiji prvi pomen datira iz 1315. godine. Priču o srednjem veku Vrdnika zaključuje manastir Vrdnik-Ravanica, koga predanje vezuje za kneza Lazara, mada je najverovatnije podignut krajem XV - početkom XVI veka.

Na području Slankamena registrovan je veliki broj lokaliteta iz perioda metalnih doba, antike i srednjeg veka. Posebno skrećemo pažnju na keltski opidum, antički Akuminkum i srednjovekovno utvrđenje na lokalitetu Gradina.

U okolini Erdevika, posebno na potesu Banja Kulina, nalazi se više termalnih izvora. Arheološka istraživawa potvrđuju da se život u praistorijskom naselju na lokalitetu Lice odvijao u periodu eneolita. Na lokalitetu Banja Kulina otkrivene su dve građevinske faze. Mlađoj fazi pripada prostrani bazen, građen od opeka povezanih malterom, koji je izvesno bio povezan sa obližnjim termalnim izvorima.

Pregled lokaliteta ukazuje da su neki od navedenih termalnih izvora izvesno bili poznati i korišćeni tokom antičkog perioda. 